\title{
Competency Capacity Building Needs of Agricultural Science Teachers in Utilization of School Farm for Skill Acquisition among Secondary School Students
}

\author{
Lawal, O.I \\ Department of Vocational Teacher Education, University of Nigeria, Nsukka, Enugu State, Nigeria \\ Onipede, Omoleye \\ Department of Vocational Teacher Education, University of Nigeria, Nsukka, Enugu State, Nigeria \\ Oketoobo, E.A \\ Department of Vocational Teacher Education, University of Nigeria, Nsukka, Enugu State, Nigeria \\ Famiwole, Remigius $\mathrm{O}$. \\ Ekiti State University, Ado-Ekiti, Nigeria
}

Received: 07-05- 2013

doi:10.7575/aiac.ijels.v.2n.3p.1
Accepted: 10-06-2013

URL: http://dx.doi.org/10.7575/aiac.ijels.v.2n.3p.1

Published: $30-07-2014$

\begin{abstract}
This study sought to identify the competency capacity building needs of teachers of agricultural science in the utilization of school farm for skill acquisition among secondary school students in Ondo State, Nigeria). Four research questions guided the study. The study adopted the survey research design. The population used was 422 , made up of teachers of agricultural science in senior secondary schools in Ondo State and 46 lecturers of agricultural education in tertiary institutions in Ondo and Ekiti States. The entire population was used for the study, hence there was no sampling. A - 33 competency items questionnaire was developed and used for data collection. The questionnaire was validated by three experts from the Department of Vocational Teachers Education (Agricultural Education Unit), University of Nigeria, Nsukka. Cronbach alpha reliability method was used to determine the internal consistency of the instrument. A reliability coefficient of 0.81 was obtained. 422 copies of the questionnaire were administered on the respondents and 406 copies were retrieved and analyzed using weighted mean and improvement need index (INI) to answer the research questions. It was found out that teachers of agricultural science in Ondo State needed capacity building in all the 33 competency items identified in the following areas, planning and organizing school farm, implementing school farm practical, coordinating and evaluating school farm practical. It was recommended, among others, that the competencies identified in this study should be utilized in organizing retraining programmes inform of seminars, workshop or long vacation courses for teachers of agricultural science in secondary schools in all states of the federation.
\end{abstract}

Key words: Competency, Capacity Building, Needs Assessment, Teachers of Agricultural Science, Skill Acquisition.

\section{Introduction}

Teachers of agricultural science in secondary schools are to impart knowledge, skills and attitudes in the area of their subject to the students. A teacher of agricultural science in the opinion of Olaitan, Asogwa and Assouzu (2010) is an individual who is trained in the pedagogical and technical areas of agricultural science and is charged with the responsibility of imparting knowledge, skills and attitudes to students. The pedagogical aspect of teaching deals with the use of selected techniques and methods to present the content (Technical areas) of agricultural science to the students in order to attain the learning objectives. The technical aspect deals with the whole content of agricultural science as indicated in the different sections and topics. This requires practical activities and experiences in the field. The teacher during instruction is mindful of the achievement of objectives of agricultural science for senior secondary schools as stated in the national curriculum by the Nigerian Education Research and Development Council (NERDC, 2009), which are: (i) to stimulate and sustain students interest in agriculture and (ii) to impart functional knowledge and practical skills in agriculture among others.

Skill, according to Alade (2006), is the physical manipulative process that culminates in the achievement of ultimate goals. In the view of Agusiobo (1987), skill is any psychomotor, manipulative or technical tasks needed for performance in any given occupation and training which could be acquired through observation, training and learning. Skill in the context of this study is the physical manipulative or technical task needed by the teachers of agricultural science in the utilization of school farm to enhance performance capabilities among the students of secondary schools. 
The acquisition of these skills can be achieved through effective use of school farms and participation in other agricultural practicals and activities.

School farm as defined by Olaitan and Mama (2001), is an area of land specially earmarked for agricultural activities. In the view of Osinem (2008), school farm is a piece of land or water used for the cultivation of crops and/or rearing of livestock or fish. The objectives of school farm as stated by Olaitan and Mama include the following.: (i) as a source of income to the school (ii) for developing skills in students (iii) for stimulating students interest as in farming and (iv) as laboratory for research among others. School farm in the context of this study is an area of land specially earmarked and utilized for teaching the students in order to develop skills, knowledge and attitudes in the cultivation of crops and rearing of animals by both students and teachers of agricultural science.

In the area of study, it was observed by the researchers that senior secondary school students did not possess the practical skills needed for crop and animal production. Also, they could not help their parents in their farming practices but were interested in products from the farm like oranges, pawpaw, maize etc. The interaction of the researchers with the teachers of agricultural science revealed that some secondary schools did not have a school farm. Also, most of the teachers of agricultural science laid more emphasis on the theoretical aspect of agricultural science and deprived the students of the practical knowledge that is needed for skill acquisition in agriculture, Experience of the researchers revealed further that the parents associated the non-acquisition of skills in agriculture by their children with the ways the teacher's handled the teaching of practical agriculture. The comment of the parents seemed to be in agreement with the study carried out by Ellah (2007), in Colleges of Education in South East Nigeria, where the author found out that the teacher of agricultural science in secondary schools in South East Nigeria acquired low competence in instructional (teaching) areas of their profession.

Teachers of agricultural science in Ondo State are graduates like their counterparts in South East Nigeria covered by the study reported above. Teachers of agricultural science in Ondo state cannot be exonerated from the author's observation and comments by the parents, hence, the non-acquisition of skills in agriculture by their students. This occurred due to much emphasis placed on theoretical aspect of teaching the subject at the detriment of the practical aspect. Since it is the responsibility of the teachers of agricultural science to equip their students with the necessary skills in agricultural activities in order to enable them develop interest and use these skills in future, the teachers need to be competent in the utilization of school farm.

Competency, according to Olaitan and Ali (1997), is the knowledge, skill, attitude and judgment generally required for successful performance of a task. In this study, competency is the knowledge, skills and attitude needed by teachers of agricultural science for effective utilization of school farm. To know the level of competency required by teachers of agricultural science, they need to be assessed.

Assessment in the view of Okoro (2000), is the process of estimating the worth quality or effectiveness of a programme or instruction through a collected data. Okoro (2000) further stated that the analyzed data will reveal the level of quality or standard of instruction or achievement of the objectives of the programme. In the context of the study, assessment is the process of determining the capacity- building needs of teachers of agricultural science for effective utilization of school farm. The process of determining the capacity building needs of teachers of agricultural science is known as Need Assessment

Anyakoha (1988) explained the concept need assessment as a type of evaluation research used in determining various areas of need or discrepancies in education. In this study, need assessment is the process of determining the difference between the level of knowledge, skills and attitude possessed by teachers of agricultural science and the level of knowledge, skills and attitude they are expected to attain for utilization of school farm to enhance skill acquisition among their students. This process gives a value called need gap. The need gap value indicates the level of capacity building needs of teachers of agricultural science in the utilization of school farm.

Capacity building in the view of Olaitan, Alaribe and Nwobu (2009) is the effort geared towards improving the level of knowledge, skills and attitude possessed by an individual for proficiency in a given task or job. In the context of this study, capacity building is the effort geared towards improving the level of knowledge, skills and attitude possessed by teachers of agricultural science in the utilization of school farm to enhance skill acquisition among senior secondary school students in Ondo state.

\section{Purpose}

The major purpose of this study was to determine competency capacity-building needs of teachers of agricultural science in the utilization of school farm to enhance skill acquisition among secondary school students in Ondo State.

\section{Research Questions}

The following research questions were raised and answered in the study

What are the capacity building competencies needed by teacher of agricultural science in:

a. planning and organizing farm practical to enhance skill acquisition among the students?

b. implementing school farm practicals to enhance skill acquisition among the students?

c. co-ordinating school farm to enhance skill acquisition among the students?

d. evaluating school farm practicals to enhance skill acquisition among the students? 


\section{Methodology}

A descriptive research of the survey type was adopted for the study. Survey research design according to Nworgu (2006) is a design in which a group of people or items are studied by collecting and analyzing data from a few people or items considered to be the representative sample. The data could be collected using either observation or interview schedule or questionnaire.

Questionnaire was used to collect data for the study. The study was carried out in Ondo State made up of nine education zones. The population of the study was 422 respondents made up of 367 teachers of agricultural science in senior secondary schools in Ondo State and 46 lecturers in tertiary institutions in Ondo State and Ekiti States. The entire population was used for the study due to the manageable size of the population hence, there was no sampling. A-33 competency item questionnaire was developed and used for data collection. The questionnaire had two scales of Needed and Performance. The needed scale had a-4 point response options of High performance, Average performance, Low performance, and No performance with corresponding value of 4,3,2, and 1 respectively.

The questionnaire was validated by three experts from the Department of Vocational Teacher Education, (Agricultural Education Unit) University of Nigeria, Nsukka. Crobanch alpha reliability method was used to determine the internal consistency of the instrument. A reliability coefficient of 0.87 was obtained. Four hundred and twenty - two copies of the questionnaire were administered on the respondents ( 376 teachers of agricultural science and 46 lecturers in tertiary institutions) 406 copies of the questionnaire were retrieved and analyzed using weighted mean and Improvement Need Index (INI) to answer the research questions.

To determine the capacity building needs of teachers of agricultural science, the following steps were taken:

(a) The weighted mean $(\mathrm{Xn}) \overline{\text { of }}$ the needed scale was determined for each item.

(b) The weighted mean (Xp) of the performance scale was determined for each item

(c) The Need Gap (NG) was determined by finding the difference between the weighted mean of the needed (Xn) and the weighted mean of the performance $(\mathrm{x}-\mathrm{p})$ of each item which is the need Gap i.e. Xn - Xp $=$ NG(Olaitan and Ndomi 2000) where:

(i) NG is negative (-) it means capacity building is not needed because the level at which the teachers could perform that item is greater than the level at which it was needed.

(ii) NG is positive (+) it means capacity - building is needed because the level at which the teachers could perform that item is lower than the level at which it was needed.

(iii) NG is Zero (0) it means capacity building is not needed because the level at which the teachers could perform that item is equal to the level at which it is needed.

\section{Results}

The results for this study were obtained from the Research Questions answered through data collected and analyzed.

\subsection{Research Question 1}

What are the capacity building competencies needed by teachers of agricultural science in planning and organizing School Farm practical to enhance skill acquisition among students?

Table 1. Need Gap Analysis of the mean scores of the respondents on the competencies needed in planning and organizing school farm practical to enhance skill acquisition among students. $* \mathrm{~N}=406$

\begin{tabular}{|c|c|c|c|c|c|}
\hline \multirow[t]{2}{*}{$* \mathrm{~S} / \mathrm{N}$} & \multirow[t]{2}{*}{ In planning, teachers need the competency to } & \multirow{2}{*}{$\begin{array}{l}* \\
\bar{X} \mathrm{n}\end{array}$} & \multirow{2}{*}{$\overline{\mathrm{X} p}$} & \multirow{2}{*}{$\begin{array}{c}{ }^{* N G} \\
\overline{\mathrm{X}} \mathrm{n}-\overline{\mathrm{Xp}}\end{array}$} & \multirow[t]{2}{*}{ REMARK } \\
\hline & & & & & \\
\hline 1. & Formulate specific objectives for the farm & 3.87 & 1.89 & 1.98 & $\begin{array}{l}\text { Capacity } \\
\text { Needed }\end{array}$ \\
\hline 2. & $\begin{array}{l}\text { Decide on farming or cropping systems to be adopted by } \\
\text { the school }\end{array}$ & 3.76 & 1.88 & 1.88 & CBN \\
\hline 3. & Draw up programme plan for the farm activities & 3.82 & 2.26 & 1.56 & CBN \\
\hline 4. & Specify type of crops to grow and animal to rear & 3.70 & 2.36 & 1.34 & $\mathrm{CBN}$ \\
\hline 5. & $\begin{array}{l}\text { Decide on the appropriate equipments for specific farm } \\
\text { operation }\end{array}$ & 3.71 & 2.40 & 1.31 & CBN \\
\hline 6. & Budget for items needed for farm operations & 3.72 & 2.41 & 1.31 & CBN \\
\hline 7. & Identify type of records to keep & 3.74 & 1.87 & 1.87 & $\mathrm{CBN}$ \\
\hline 8. & $\begin{array}{l}\text { Present list of inputs needed and their cost to the } \\
\text { principal }\end{array}$ & 3.72 & 1.83 & 1.89 & CBN \\
\hline 9. & $\begin{array}{l}\text { Identify other sources of obtaining financial support for } \\
\text { the farm inputs }\end{array}$ & 3.70 & 1.82 & 1.88 & CBN \\
\hline
\end{tabular}




\begin{tabular}{|c|c|c|c|c|c|}
\hline 10. & Procure farm inputs for the farm & 3.73 & 1.80 & 1.93 & $\mathrm{CBN}$ \\
\hline 11. & Organize farm activities through the use of farm calendar & 3.70 & 1.89 & 1.81 & $\mathrm{CBN}$ \\
\hline 12. & $\begin{array}{l}\text { Arrange available resources sequentially for effective } \\
\text { use }\end{array}$ & 3.66 & 1.94 & 1.72 & $\mathrm{CBN}$ \\
\hline 13. & Assign specific tasks on the farm to the students & 3.85 & 1.89 & 1.96 & $\mathrm{CBN}$ \\
\hline
\end{tabular}

Key: $\mathrm{CBN}=$ Capacity Building Needed

Data in Table 1 revealed that all the 13 competency items had their need gap values ranged from 1.31 to 1.98 and were positive. This showed all the 13 competencies are needed by the teachers of Agricultural science for capacity building to enhance skill acquisition among the students studying agricultural science.

\subsection{Research Question 2}

What are the capacity building competencies needed by teachers of agricultural science in implementing school farm practical to enhance skill acquisition among students?

Table 2. Need Gap analysis of the mean scores of the responses of teachers of agricultural science on competencies needed in implementing school farm practical.

\begin{tabular}{|c|c|c|c|c|c|}
\hline $\mathrm{S} / \mathrm{N}$ & $\begin{array}{l}\text { Item Statement } \\
\text { Competencies Needed }\end{array}$ & $\overline{\mathrm{X}} \mathrm{n}$ & $\overline{\mathrm{Xp}}$ & $\frac{\mathrm{NG}}{\mathrm{Xn}-\overline{\mathrm{Xp}}}$ & REMARK \\
\hline 1. & $\begin{array}{l}\text { Adhere strictly to the programme of farm activities } \\
\text { for the school }\end{array}$ & 3.77 & 2.17 & 1.60 & $\mathrm{CBN}$ \\
\hline 2. & Lay out the school farm & 3.57 & 2.02 & 1.73 & $\mathrm{CBN}$ \\
\hline 3. & $\begin{array}{l}\text { Review the programme of the farm activities } \\
\text { periodically }\end{array}$ & 3.66 & 2.04 & 1.62 & $\mathrm{CBN}$ \\
\hline 4. & Prepare farmland for planting & 3.69 & 2.06 & 1.63 & $\mathrm{CBN}$ \\
\hline 5. & $\begin{array}{l}\text { Rear specific animals on the farm } \\
\text { and manage them well }\end{array}$ & 3.73 & 1.92 & 1.81 & $\mathrm{CBN}$ \\
\hline 6. & $\begin{array}{l}\text { Grow specific crops on the farm and manage them } \\
\text { well }\end{array}$ & 3.72 & 2.00 & 1.72 & $\mathrm{CBN}$ \\
\hline 7. & $\begin{array}{l}\text { Prepare and formulate feed for different types of } \\
\text { livestock on the farm }\end{array}$ & 3.66 & 1.92 & 1.74 & $\mathrm{CBN}$ \\
\hline 8. & Apply appropriate fertilizers to farm crops. & 3.73 & 1.78 & 1.95 & $\mathrm{CBN}$ \\
\hline
\end{tabular}

Data in Table 2 showed that the need gap values of the 8 competency items ranged from 1.60 to 1.95 and were positive. This indicated that the teachers of agricultural science needed capacity building in the eight competency development areas.

\subsection{Research Question 3}

What are the capacity building competencies needed by teachers of agricultural science on coordinating school farm practical to enhance skill acquisition among students?

Table 3. Need Gap Analysis of the mean scores of the responses of the Teachers of Agricultural science on competencies needed in coordinating school farm practical.

\begin{tabular}{|c|c|c|c|c|c|}
\hline \multirow[t]{2}{*}{$\mathrm{S} / \mathrm{N}$} & \multicolumn{3}{|l|}{ Item Statement } & \multirow{2}{*}{$\frac{\mathrm{NG}}{\mathrm{Xn}}-\overline{\mathrm{Xp}}$} & \multirow[t]{2}{*}{ REMARK } \\
\hline & To co-ordinate school farm practicals, teachers need to & $\overline{\mathrm{X}} \mathrm{n}$ & $\overline{\mathrm{Xp}}$ & & \\
\hline 1. & Interpret properly the objectives of school farm & 3.70 & 2.14 & 1.57 & $\mathrm{CBN}$ \\
\hline 2. & $\begin{array}{l}\text { Set up committees to interpret different activities being } \\
\text { performed by the students on the school farm }\end{array}$ & 3.67 & 1.91 & 1.76 & $\mathrm{CBN}$ \\
\hline 3. & $\begin{array}{l}\text { Get adequate supply and } \\
\text { utilization of material resources for practical }\end{array}$ & 3.79 & 1.76 & 2.03 & $\mathrm{CBN}$ \\
\hline 4. & Guide the students in the use of materials and machines. & 3.76 & 1.78 & 1.89 & $\mathrm{CBN}$ \\
\hline 5. & Monitor the activities of individual students on the school. & 3.71 & 1.80 & 1.91 & $\mathrm{CBN}$ \\
\hline 6. & $\begin{array}{l}\text { Follow approved farm procedures and practices on the } \\
\text { school farm. }\end{array}$ & 3.76 & 1.79 & 1.97 & $\mathrm{CBN}$ \\
\hline
\end{tabular}


Table 3 revealed that all the 6 competencies had their need gap values ranged from 1.57 to 2.03 and were positive. This showed that the teachers of agricultural science needed capacity building in all the six competency development units.

\subsection{Research Question 4}

What are the capacity building competencies needed by teachers of agricultural science to evaluating school farm practical's in other to enhance skill acquisition among students?

Table 4. Need Gap analysis of the mean scores of the responses of teachers of agricultural science on competencies needed to evaluate school farm practicals.

\begin{tabular}{|c|c|c|c|c|c|}
\hline \multirow[t]{2}{*}{$\mathrm{S} / \mathrm{N}$} & \multirow[t]{2}{*}{ The needed competencies are: } & \multirow[b]{2}{*}{$\overline{\mathrm{X}} \mathrm{n}$} & \multirow[b]{2}{*}{$\overline{\mathrm{X} p}$} & \multirow{2}{*}{$\frac{\mathrm{NG}}{\mathrm{Xn}-\overline{X p}}$} & \multirow[t]{2}{*}{ REMARK } \\
\hline & & & & & \\
\hline 1. & Identify the key points to be evaluated & 3.73 & 1.75 & 1.98 & $\mathrm{CBN}$ \\
\hline 2. & $\begin{array}{l}\text { State the objectives of the school farm so that evidence of } \\
\text { the degree to which the objectives are being achieved can } \\
\text { be obtained }\end{array}$ & 3.69 & 1.66 & 2.03 & $\mathrm{CBN}$ \\
\hline 3. & Evaluate students demonstration through rating & 3.72 & 1.71 & 2.01 & $\mathrm{CBN}$ \\
\hline 4. & $\begin{array}{l}\text { Assess students practical work through psycho productive } \\
\text { test }\end{array}$ & 3.75 & 1.72 & 2.03 & $\mathrm{CBN}$ \\
\hline 5. & $\begin{array}{l}\text { Provide feedback to the students on their performance or to } \\
\text { their parents on the performance of their wards }\end{array}$ & 3.70 & 1.74 & 1.96 & $\mathrm{CBN}$ \\
\hline 6. & Keep students performance record & 3.78 & 1.723 & 2.03 & $\mathrm{CBN}$ \\
\hline
\end{tabular}

Key: CBN = Capacity Building Needed

Data in Table 4 showed that all the competencies had their need gap values ranged from 1.96 to 2.06 and were positive. This showed that the teachers of agricultural science needed capacity building in all the competencies items.

\section{Discussion}

The finding of the study in Table 1 revealed that the teachers of agricultural science needed capacity building in all the competency items in planning and organizing school farm. In Table 2, they needed capacity building in all the competencies required for implementing school farm practicals; in Table 3, they needed capacity building in all the competency items in coordinating school farm practicals and table 4 showed that the teachers of agricultural science needed capacity building in all the competency items in evaluating school farm practicals.

The findings of this study are in conformity with the findings of Amusa's (2009) study which looked into competency improvement needs of fanners in cocoyam production in Ekiti State, Nigeria; where it was found out that farmers required improvement in competencies in planning, planting, post planting, processing, preservation and storage operations of cocoyam.

The findings of this study are also in consonance with the findings of Akwaji's (2006) study which was carried out on work - skill required by secondary school graduates for success in cassava processing enterprise in CrossRiver State. The author found out that secondary school graduates required work-skills in processing cassava into garri, flour, chips and starch.

The findings are also in agreement with the findings of Abu (2008), in a study on competency improvement needs of farmers in soil conservation in Kogi State, Nigeria. The author found out that farmers needed improvement in getting rid of stubbles from cereals before tillage, tilling the soil to specification, burying crop residue before planting, making ridges across the slope and making use of machines and implements to till the soil.

\section{Conclusion}

The findings of this study have justified the need for capacity building of teachers on how to effectively use the school farm to enhance skill development among secondary school students. Observations and interactions of the researcher with the senior secondary school students in the area of study revealed that they did not possess the practical skills needed for crop and animal production as stipulated in the curriculum; hence, these students could not help their parents on their farm practices. The researcher's interaction with the teachers of agricultural science in the study area showed that some secondary schools did not have school farm where the students could be taught how to acquire relevant entrepreneurial and saleable skills in the practical aspects of the subject. Moreover, most of the teachers were used to laying emphasis on the theoretical aspect of agricultural science thereby depriving the students of the practical knowledge that was needed for skill acquisition.

Experience and interaction of the researcher further revealed that the parents of the students associated the nonacquisition of skills by their children in agriculture with the ways the teachers handled the teaching of practical 
agriculture in school and colleges. This study therefore, determined competency capacity building needs of teachers of agricultural science in the utilization of school farm to enhance skill acquisition among secondary schools students in Ondo state. It was found out that teachers of agricultural science needed improvement in all the 33 competency items identified.

\section{Recommendations}

Arising from the findings of this study, the following are recommended;

1. The competencies identified in this study should be utilized to organize retraining programmes in form of seminars, workshops or long vacation courses for teachers of agricultural science on how to effectively use the school farm to enhance skill acquisition among secondary school students.

2. All secondary schools in the country should be encouraged to establish a well managed school farm.

3. A unit should be established at the State Ministry of Education to monitor, co-ordinate and evaluate the activities of school farm in all state of the federation.

4. All students of Junior Secondary School 1-3 and those offering agricultural science in Senior Secondary School 1-3 should be motivated to have individual farm work/pilot, and should be frequently evaluated by the teacher of agriculture.

\section{References}

Abu. M (2008), Competency Improvement Needs of Farmers in Soil Conservation in Kogi State. Unpublished M.Ed Project Department of Vocational Teacher Education, University of Nigeria, Nsukka.

Agusiobo, O.N(1987), Identification of Essential Trait and Task of Selected Clothing Occupation for Senior Secondary School Students In Anambra And Imo States Of Nigeria. Unpublished Phd thesis, Department of Vocational Teacher Education, University of Nigeria, Nsukka.

Akwaji .I.T (2006) Work Skills Required by Secondary School Graduates for Success in Cassava Production Enterprises in Cross River State Nigeria. Unpublished M.Ed Thesis, Department of Vocational Teacher Education, University of Nigeria, Nsukka.

Alade, I. A (2009), Evaluation of Technical Education Curriculum in Colleges of Education

in South Western Nigeria. Phd Thesis, Department of Vocational Teacher Education, University of Nigeria, Nsukka.

Amusa, T.A (2009), Competency Improvement needs of Farmers in Cocoyam Production in Ekiti State Nigeria. Unpublished PGDTE Thesis, Department of Vocational Teacher Education, University of Nigeria, Nsukka.

Anyakoha. E.U (1988), Other Types of Research Studies: Practical Research Methods in Education: Onitsha: Summer Educational publishers limited.

Ellah, B.I (2001), Principles and Skills Relevant to Effective Utilization of School Farm in Secondary Schools in Cross River State. Unpublisjhed M.Ed Thesis, Department of Vocational Teacher Education, University of Nigeria, Nsukka.

NERDC (2009), National Agricultural Science Curriculum. Abuja. Nsukka. University Trust Publishers.

Nworgu, B.G (2006), Educational; Research: Basic Issues and Methodology. Nsukka. University Trust Publishers.

Okoro, O.M (2000), Pragramme Evaluation in Education. Urouwulu - Obosi: pacific publishers.

Olaitan. S.O, Alanbe, M.O \& Nwobu, V.I (2009) Capacity Building Needs of Teachers of Agriculture for Effective Teaching in Basic Schools in Abia State; A paper presented at the Annual conference of Faculty of Education, University of Nigeria, Nsukka.

Olaitan, S.O \& Ali, A. (1997), The Making of Curriculum Theory, Process, Product in and Evaluation Onitsha: Cape Publishers.

Olaitan, S.O; Asogwa, V.C \& Asougu. I (2010), Quality Assurance of Women in Agriculture in Processing Barbara Groundnut into Okpa in Anambra State. A paper presented at the Annual Conference of Faculty of Education, University of Nigeria, Nsukka.

Olaitan. S.O \& Mama, R.O (2001), Principles and Practice of school Farm Management: Oweri; Nigeria: cape publishers limited.

Osinem, E.C (2008), Managing Agricultural Education and Training, Resources, Principles and Methods: Enugu: Belony International Publishers. 